\title{
EVALUATION OF REPRODUCTIVE SUCCESS AND CONSERVATION STRATEGIES FOR SENECIO COINCYI (ASTERACEAE), A NARROW AND THREATENED ENDEMIC PLANT OF CENTRAL WESTERN SPAIN
}

\author{
FELIPE MARTÍNEZ-GARCÍA ${ }^{1}$, SILVIA GUERRERO-GARCÍA ${ }^{1}$ and FÉLIX PÉREZ-GARCÍA \\ ${ }^{1}$ Departamento de Silvopascicultura, Escuela Técnica Superior de Ingenieros de Montes, Universidad Politéenica de \\ Madrid, 28040 Madrid, Spain \\ ${ }^{2}$ Departamento de Biología Vegetal, Escuela Universitaria de Ingeniería Técnica Agricola, Universidad Politécnica de \\ Madrid, 28040 Madrid, Spain
}

\begin{abstract}
Senecio coincyi (Asteraceae) is a threatened endemic plant of central western Spain. The reproductive biology of this species in relation to the characteristics of its habitats and the possible strategies for its conservation, were studied. The area of occupancy, habitat types and size of 13 known subpopulations of $S$. coincyi was evaluated. Germination tests were carried out to assess the effect of temperature and light regimes, and the possible intraspecific variation on the cypsela germination. Cypselas reached very high germination percentages (90-100\%) from $15^{\circ} \mathrm{C}$ to $30^{\circ} \mathrm{C}$. However, the germination decreased (by about $19 \%$ ) at $10^{\circ} \mathrm{C}$. The light conditions assayed did not significantly affect cypsela germination. In conclusion, $S$. coincyi showed high sexual reproduction ability, and therefore its conservation problems are not due to agents related to its reproductive biology, but to others, such as the alteration of its habitat caused by the presence of livestock.
\end{abstract}

Key words: Cypsela germination, intraspecific variability, plant conservation, reproductive biology, Senecio coincyi, Spain

\section{INTRODUCTION}

All Mediterranean-climate regions have a high number of rare and locally endemic taxa that survive as small populations, many of which are threatened by habitat transformation (Cowling et al., 1996). High levels of endemic species are a significant feature of Mediterranean mountains (Gavilán et al., 2002; Väre et al., 2003; Giménez-Benavides et al., 2005). Global warming evidence in the mountains of central Spain (Gavilán et al., 2001; Sanz-Elorza et al., 2003) suggest that mountain species are at serious risk from the advance of lowland plants, as widely predicted (Grabherr et al., 1994; Peñuelas et al., 2002). There is almost no basic information for the conservation of these plants despite the fact that Mediterranean mountains are considered one of the most threatened systems in Spain and the European Union (GómezCampo, 1987).

Senecio coincyi Rouy (Asteraceae) is a narrow and threatened endemic species of the Iberian Peninsula with a distribution restricted to a very small area of the Sierras of Villafranca and Gredos (Âvila province, central western Spain) (Fig. 1). Since 1985 this taxon is included in successive catalogues of threatened species of Spain (Barreno, 1985; GómezCampo, 1987; Domínguez, 2000; Moreno, 2008). The species was included in the "In danger of extinction" category in the protected flora catalogue of the Autonomous Community of Castile and León (Spain) (Anonymous, 2007). It was later catalogued as Vulnerable (VU) in the Red List 2008 of Threatened Spanish Vascular Flora (Martínez García et al., 2008). 
Despite its status as a threatened and protected species, at present it is a species of which very little is known.

S. coincyi was described for first time by Rouy (1890) from plants herborized by Coincy at Pinar Hoyocasero (Ávila province, Spain), a location where this species is now considered to be extinct. It belongs to the S. integrifolius (L.) Clairv. group (Tutin et al., 1964-1980), widely distributed on the mountains of Europe. S. coincyi is a hygrophilous, hemicryptophyte, perennial taxon whose leaves form a basal rosette that emits a floriferous stem up to $1.5 \mathrm{~m}$ high. The flower scape blooms in June and fruits from late June to July. Its flowers are grouped into capitulaforming corymbs, with about 10-20 thick capitula, and they are pollinated by several insects species. The fruit is a ribbed fusiform cypsela, between 3 and $5 \mathrm{~mm}$ in length and less than $1 \mathrm{~mm}$ in diameter, with a pappus that facilitates its dispersion by wind. Therefore, it is an entomophilous and anemochorous species.

Most of the subpopulations (according to IUCN terminology; IUCN, 2010) of $S$. coincyi are found at an altitude between $1500 \mathrm{~m}$ and $1800 \mathrm{~m}$, although there are some subpopulations located at $1300 \mathrm{~m}$ and others up to $1900 \mathrm{~m}$. The species inhabits wet siliceous soils with a permanently high level of edaphic humidity throughout the year. For this reason, it grows exclusively on the edges of streams, hay meadows that in many cases are abandoned, peaty meadows and small peat bogs. Mean annual precipitation in areas where $S$. coincyi grows ranges from $800 \mathrm{~mm}$ to $970 \mathrm{~mm}$. The mean annual temperature is around $8-11^{\circ} \mathrm{C}$, with a mean maximum temperature in the warmest month of $19-21^{\circ} \mathrm{C}$ and a mean minimum temperature in the coldest month of $0.3-2.2^{\circ} \mathrm{C}$ (Ninyerola et al., 2005).

To evaluate the conservation status of a species it is essential to know where and how their mature individuals are distributed (Iriondo et al., 2009). Once its extent of occurrence (IUCN, 2010) and, within it its different subpopulations are identified, the next step is to determine how many mature individuals form the species and, more specifically, each one of their subpopulations (Iriondo et al., 2009). The results of the chorology and census of the species are essentials to apply criteria for establishing the degree of threat (IUCN, 2010) and possible conservation strategies.

There are few studies about the germination behavior of mountain endemic species from Iberian Peninsula (Pérez-García et al., 1995; Albert et al., 2002; Giménez-Benavides et al., 2005; Lorite et al., 2007). Similarly, little information is available on the seed germination of Senecio species (Fernández et al., 2011; Kirmizi et al., 2011). This is the first study about germinative characteristics of $S$. coincyi.

In this work, the results of two-year-long explorations of $S$. coincyi subpopulations are shown. The aims of this study were to: 1) study several aspects of $S$. coincyi reproductive biology; 2) analyze the effects of intraspecific variability upon cypsela germination; 3) provide useful information on germination conditions for conservation purposes; 4) evaluate the conservation status and determine the degree of threat of this species, and 5) develop management proposals and protection measures for the conservation of S. coincyi.

\section{MATERIALS AND METHODS}

\section{Chorology and census of the subpopulations}

Data about the area of occupancy, altitude, habitat types, size and conservation status were collected for each one of the 13 known subpopulations of $S$. coincyi. In addition, the impact of human activities or any other alteration of the environment was evaluated. A total of 62 UTM square $(1 \times 1 \mathrm{~km})$ in the Sierras of Villafranca and Gredos (central western Spain) (Fig. 1) were visited to evaluate the number of mature individuals per subpopulation. Groups of individuals who were separated from each other by a distance greater than $1 \mathrm{~km}$ were considered to belong to different subpopulations, the gene flow among them being sporadic or negligible (Iriondo, 2003). 


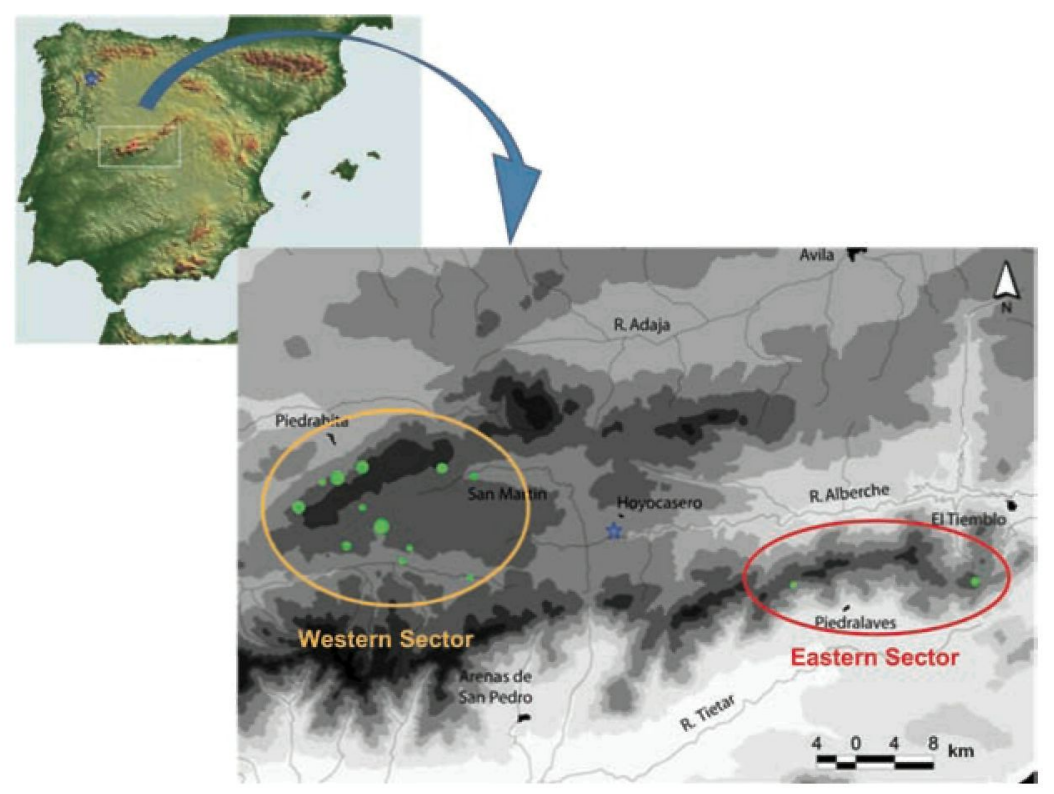

Fig. 1. Distribution of the known subpopulations of Senecio coincyi (green circles). The blue start indicates an extinct subpopulation.

A count of individuals, one by one, was carried out in most visited subpopulations. In some areas of the subpopulation studied, it was extremely difficult to carry out this type of count due to individuals being close together or inaccessible. An estimation of the number of individuals was carried out in these cases. For this, all individuals present in a reference plot were counted one by one, and then this value of density was extrapolated to the approximate surface of the area to census. The characteristics and number of mature individuals of 13 known subpopulations of S. coincyi are shown in Table 1. All these subpopulations were located in the Sierras of Villafranca and Gredos (Âvila province, central western Spain) (Fig. $1)$.

\section{Number of flowers and fruits per capitulum}

Personal field observations were carried out to know which insect species visited the flowers of $S$. coincyi daily. The flowers are grouped into capitula (fruit heads hereafter) from a floriferous stem, so that there was only an individual plant per floriferous stem. In June 2007, unripe fruit heads from individuals chosen at random out of 7 subpopulations (HER1, HER2, HOY, NAM, PIE1, PIE2, TIE) (Table 1) were collected. The number of fruit heads collected was proportional to the subpopulation size (see Table 3). Thus, for the bigger subpopulations (HER2 and PIE2), 43 and 22 fruit heads were taken, while for the smaller ones only 7-12 fruit heads were collected. The number of ligulate, tubular and total flowers per fruit head was subsequently recorded in the laboratory.

In July 2007, ripe fruit heads chosen at random from several individuals randomly chosen of 6 subpopulations (HER2, HOY, NAV1, NAV2, PIE1, SAN) (Table 1) were collected. The number of fruit heads sampled from each subpopulation ranged from 4 to 19 depending on the subpopulation (see Table 4). All fruit heads collected contained ripe fruits (hereafter cypselas). The number of cypselas per single fruit head was recorded in the laboratory. In addition, the total number of ripe fruit heads per individual plant was recorded for 5 subpopulations (HER2, HOY, NAV1, PIE1, SAN). The number of plants randomly sampled from each subpopulation ranged from 6 to 45 , depending on the subpopulation size (see Table 5).

At the beginning of June 2007, a number of unripe fruit heads from subpopulations HER2, HOY 
Table 1. Subpopulation code, location, UTM coordinates, altitude, surface occupied, and population size related to the Senecio coincyi locations known. All subpopulations are located in the Sierras of Villafranca and Gredos (Ávila province, central western Spain, see Figure 1).

\begin{tabular}{|c|c|c|c|c|c|c|c|}
\hline Subpop. code & Location & Sector & $\begin{array}{l}\text { Altitude } \\
\text { ( } \mathrm{m} \text { a.s.l.) }\end{array}$ & $\begin{array}{l}\text { UTM square } \\
\text { of reference }\end{array}$ & $\begin{array}{l}\text { Number of } \\
\text { UTM squares }\end{array}$ & $\begin{array}{l}\text { Surface } \\
\text { (ha) }\end{array}$ & $\begin{array}{l}\text { Number of } \\
\text { individuals }\end{array}$ \\
\hline NAM & Navamuñana & Western & $1700-1750$ & 30TTK9974 & 3 & 4.1 & 3570 \\
\hline NAL & Navalmahillo & Western & $1450-1500$ & 30TUK0177 & 2 & 0.2 & 391 \\
\hline PIE1 & Piedrahita & Western & $1750-1850$ & 30TUK0377 & 2 & 0.5 & 1895 \\
\hline PIE2 & Piedrahita & Western & $1750-1900$ & 30TUK0679 & 4 & 1.7 & 4,217 \\
\hline SAN & San Martín & Western & $1580-1600$ & $30 \mathrm{TUK} 1478$ & 3 & 2.4 & 1927 \\
\hline HER1 & La Herguijuela & Western & $1650-1800$ & 30TUK0574 & 3 & 0.1 & 43 \\
\hline HER2 & La Herguijuela & Western & $1500-1700$ & 30TUK0873 & 5 & 11.2 & 10179 \\
\hline ORT & Ortigosa & Western & $1450-1570$ & $30 \mathrm{TUK} 0470$ & 2 & 1.5 & 1211 \\
\hline NAV1 & Navacepeda & Western & 1600 & $30 \mathrm{TUK} 1069$ & 1 & 0.1 & 113 \\
\hline $\mathrm{NAV} 2$ & Navacepeda & Western & $1300-1600$ & 30TUK1071 & 2 & 4.3 & 304 \\
\hline $\mathrm{HOY}$ & Hoyos del Espino & Western & 1470 & $30 \mathrm{TUK} 1767$ & 3 & 1.7 & 436 \\
\hline $\mathrm{PEV}$ & Piedralaves & Eastern & $1360-1400$ & $30 T U K 4967$ & 1 & 0.9 & 500 \\
\hline TIE & El Tiemblo & Eastern & 1550 & $30 \mathrm{TUK} 6867$ & 2 & 1.2 & 827 \\
\hline
\end{tabular}

Table 2. Surface estimated of the different habitat types where Senecio coincyi inhabits.

\begin{tabular}{ccc}
\hline Habitat type & Surface (ha) & \% of the total surface \\
\hline Edges of streams & 15.1 & 50.7 \\
Hay meadows & 8.6 & 28.8 \\
Peaty meadows & 5.0 & 16.8 \\
Water pipes & 0.8 & 2.7 \\
Peat bogs & 0.3 & 1.0 \\
Total surface & 29.8 & 100 \\
\hline
\end{tabular}

Table 3. Mean and standard error $( \pm \mathrm{SE})$ of number of ligulate, tubular and total flowers per fruit head for seven subpopulations of Senecio coincyi. $\mathrm{N}=$ Number of fruit heads sampled from each subpopulation.

\begin{tabular}{ccccr}
\hline Subpop. code & $\begin{array}{c}\text { Ligulate } \\
\text { flowers }\end{array}$ & $\begin{array}{l}\text { Tubular } \\
\text { flowers }\end{array}$ & $\begin{array}{c}\text { Total } \\
\text { flowers }\end{array}$ & $\mathrm{N}$ \\
\hline HER1 & $19 \pm 0.83$ & $119 \pm 12.05$ & $138 \pm 12.56$ & 11 \\
HER2 & $19 \pm 0.48$ & $134 \pm 5.09$ & $153 \pm 5.60$ & 43 \\
HOY & $15 \pm 0.81$ & $131 \pm 12.40$ & $146 \pm 12.90$ & 8 \\
NAM & $19 \pm 0.89$ & $140 \pm 7.58$ & $159 \pm 8.31$ & 12 \\
PIE1 & $21 \pm 0.68$ & $160 \pm 7.78$ & $181 \pm 7.71$ & 7 \\
PIE2 & $20 \pm 0.65$ & $138 \pm 6.60$ & $158 \pm 7.09$ & 22 \\
TIE & $17 \pm 1.06$ & $124 \pm 9.57$ & $141 \pm 11.44$ & 11 \\
\hline
\end{tabular}


Table 4. Mean and standard error $( \pm \mathrm{SE})$ of number of cypselas per a single fruit head for six subpopulations of Senecio coincyi. The number of cypselas was recorded for fruit heads with (bagged) or without (non-bagged) paper bag. $N=$ number of fruit heads sampled from each subpopulation.

\begin{tabular}{crrcc}
\hline Subpop. code & Bagged & N & Non-bagged & N \\
\hline HER2 & $145 \pm 7.27$ & 19 & $159 \pm 7.43$ & 17 \\
HOY & $160 \pm 10.88$ & 5 & $154 \pm 9.15$ & 9 \\
NAV1 & $166 \pm 21.43$ & 4 & - & - \\
NAV2 & $132 \pm 8.02$ & 14 & - & - \\
PIE1 & $145 \pm 8.42$ & 17 & $180 \pm 13.30$ & 15 \\
SAN & $152 \pm 14.43$ & 9 & - & - \\
\hline
\end{tabular}

Table 5. Number of fruit heads per individual plant for five subpopulations of Senecio coincyi. $\mathrm{N}=$ Number of individuals sampled from each subpopulation.

\begin{tabular}{crc}
\hline Subpop. code & Mean \pm SE & N \\
\hline HER2 & $15 \pm 0.78$ & 45 \\
HOY & $8 \pm 0.55$ & 24 \\
NAV1 & $12 \pm 1.36$ & 6 \\
PIE1 & $13 \pm 1.66$ & 32 \\
SAN & $13 \pm 2.19$ & 20 \\
\hline
\end{tabular}

Table 6. Effect of different temperature regimes on the final germination percentage and mean germination time (MGT) of Senecio coincyi cypselas belonging to two subpopulations. The number of empty cypselas in each replicate was had into account for calculating the final germination percentage. Results after 20 days of incubation $\left(40\right.$ days at $10^{\circ} \mathrm{C}$ ) under a $16-\mathrm{h}$ light photoperiod.

\begin{tabular}{cccc}
\hline $\begin{array}{c}\text { Subpop. } \\
\text { code }\end{array}$ & $\begin{array}{c}\text { Incubation } \\
\text { temperature }\end{array}$ & $\begin{array}{c}\text { Germination } \\
(\% \pm \mathrm{SE})\end{array}$ & $\begin{array}{c}\text { MGT } \\
\text { (days } \pm \mathrm{SE})\end{array}$ \\
\hline HER2 & $10^{\circ} \mathrm{C}$ & $19 \pm 3.79 \mathrm{a}$ & $13.45 \pm 0.26 \mathrm{c}$ \\
& $15^{\circ} \mathrm{C}$ & $98 \pm 2.00 \mathrm{~b}$ & $7.96 \pm 0.14 \mathrm{~b}$ \\
& $20^{\circ} \mathrm{C}$ & $98 \pm 1.18 \mathrm{~b}$ & $6.11 \pm 0.10 \mathrm{a}$ \\
& $25^{\circ} \mathrm{C}$ & $100 \mathrm{~b}$ & $5.87 \pm 0.10 \mathrm{a}$ \\
& $30^{\circ} \mathrm{C}$ & $92 \pm 3.90 \mathrm{~b}$ & $6.68 \pm 0.44 \mathrm{a}$ \\
NAV2 & $25 / 15^{\circ} \mathrm{C}$ & $98 \pm 1.20 \mathrm{~b}$ & $6.10 \pm 0.04 \mathrm{a}$ \\
& $20^{\circ} \mathrm{C}$ & $98 \pm 1.00 \mathrm{a}$ & $7.77 \pm 0.32 \mathrm{a}$ \\
& $25^{\circ} \mathrm{C}$ & $90 \pm 3.75 \mathrm{a}$ & $7.12 \pm 0.44 \mathrm{a}$ \\
& $25 / 15^{\circ} \mathrm{C}$ & $91 \pm 5.92 \mathrm{a}$ & $7.55 \pm 0.43 \mathrm{a}$ \\
\hline
\end{tabular}

For each subpopulation, mean within a column followed by the same letters are not significantly different according to the LSD test at 0.05 level.

Table 7. Final germination percentage and mean germination time (MGT) of Senecio coincyi cypselas belonging to six subpopulations. The number of empty cypselas in each replicate was taken into account for calculating the final germination percentage. Results after 20 days of incubation under a 16 -h light photoperiod at $25 / 15^{\circ} \mathrm{C}$.

\begin{tabular}{cccc}
\hline $\begin{array}{c}\text { Subpop. } \\
\text { code }\end{array}$ & $\begin{array}{c}\text { Empty cypselas } \\
(\% \pm \mathrm{SE})\end{array}$ & $\begin{array}{c}\text { Germination } \\
(\% \pm \mathrm{SE})\end{array}$ & $\begin{array}{c}\text { MGT } \\
(\text { days } \pm \mathrm{SE})\end{array}$ \\
\hline HER2 & $19 \pm 7.19 \mathrm{~b}$ & $88 \pm 5.36 \mathrm{a}$ & $7.50 \pm 0.31 \mathrm{ab}$ \\
NAV1 & $15 \pm 6.81 \mathrm{ab}$ & $97 \pm 1.99 \mathrm{ab}$ & $6.93 \pm 0.23 \mathrm{a}$ \\
PIE1 & $11 \pm 3.42 \mathrm{ab}$ & $93 \pm 3.75 \mathrm{ab}$ & $7.52 \pm 0.61 \mathrm{ab}$ \\
PEV & $1 \pm 1.00 \mathrm{a}$ & $98 \pm 1.66 \mathrm{~b}$ & $8.11 \pm 0.29 \mathrm{bc}$ \\
SAN & $0 \mathrm{a}$ & $99 \pm 0.87 \mathrm{~b}$ & $8.45 \pm 0.15 \mathrm{bc}$ \\
TIE & $42 \pm 9.02 \mathrm{c}$ & $88 \pm 4.37 \mathrm{a}$ & $8.91 \pm 0.23 \mathrm{c}$ \\
\hline
\end{tabular}

Means followed by the same letters in a column are not significantly different according to the LSD test at 0.05 level. 
Table 8. Final germination percentages and mean germination time (MGT) of Senecio coincyi cypselas belonging to 13 individual plants from the subpopulation HER2 and 12 plants from the subpopulation SAN. The number of empty cypselas in each replicate was taken into account for calculating the final germination percentage. Results after 20 days of incubation under a 16-h light photoperiod at $25 / 15^{\circ} \mathrm{C}$.

\begin{tabular}{|c|c|c|c|}
\hline $\begin{array}{l}\text { Subpop. } \\
\text { code }\end{array}$ & $\begin{array}{c}\text { Empty cypselas } \\
(\% \pm \mathrm{SE})\end{array}$ & $\begin{array}{l}\text { Germination } \\
(\% \pm \mathrm{SE})\end{array}$ & $\begin{array}{c}\text { MGT } \\
\text { (days } \pm \text { SE) }\end{array}$ \\
\hline \multirow[t]{13}{*}{ HER2 } & 0 & 100 & $10.30 \pm 0.26$ \\
\hline & $46 \pm 2.00$ & $96 \pm 3.85$ & $10.50 \pm 0.50$ \\
\hline & 0 & $98 \pm 2.00$ & $6.57 \pm 0.19$ \\
\hline & $8 \pm 0.00$ & $98 \pm 2.17$ & $10.23 \pm 0.23$ \\
\hline & 0 & 100 & $10.54 \pm 0.46$ \\
\hline & $4 \pm 2.83$ & 100 & $8.48 \pm 0.44$ \\
\hline & $2 \pm 1.41$ & 100 & $8.08 \pm 0.24$ \\
\hline & $20 \pm 5.66$ & $84 \pm 10.86$ & $10.37 \pm 0.81$ \\
\hline & 0 & 100 & $7.54 \pm 0.00$ \\
\hline & $14 \pm 7.07$ & 100 & $9.65 \pm 0.03$ \\
\hline & $4 \pm 2.83$ & $94 \pm 2.35$ & $9.35 \pm 0.73$ \\
\hline & $18 \pm 1.41$ & $95 \pm 5.00$ & $8.08 \pm 0.08$ \\
\hline & $14 \pm 1.41$ & $91 \pm 4.44$ & $10.39 \pm 0.39$ \\
\hline $\mathrm{P}$ & 0.0004 & 0.0747 & 0.0001 \\
\hline \multirow[t]{11}{*}{ SAN } & $\begin{array}{r}44 \pm 5.66 \\
8 \pm 2.83\end{array}$ & $\begin{array}{c}90 \pm 10.00 \\
100\end{array}$ & $\begin{array}{l}7.87 \pm 0.37 \\
8.02 \pm 0.48\end{array}$ \\
\hline & $2 \pm 1.41$ & $94 \pm 2.35$ & $9.71 \pm 0.05$ \\
\hline & 0 & $96 \pm 0.00$ & $10.46 \pm 0.62$ \\
\hline & 0 & $98 \pm 0.00$ & $7.60 \pm 0.15$ \\
\hline & $2 \pm 1.41$ & 100 & $7.65 \pm 0.31$ \\
\hline & $10 \pm 4.24$ & 100 & $7.68 \pm 0.09$ \\
\hline & $10 \pm 6.00$ & $98 \pm 2.17$ & $8.93 \pm 0.12$ \\
\hline & $2 \pm 1.41$ & 100 & $7.89 \pm 0.11$ \\
\hline & $2 \pm 1.41$ & $98 \pm 2.17$ & $8.14 \pm 0.28$ \\
\hline & 0 & 100 & $6.50 \pm 0.10$ \\
\hline & $8 \pm 5.66$ & $95 \pm 0.11$ & $9.75 \pm 0.84$ \\
\hline $\mathrm{P}$ & 0.0094 & 0.2821 & 0.0001 \\
\hline
\end{tabular}

$P$ significant values in bold.

and PIE 1 were bagged in fine paper bags. This was done to be sure that no cypsela fell from the fruit head and was lost, because cypselas have a pappus for wind dispersal. The bags were very thin and they allowed transpiration and the passage of light. Mature fruit heads bagged were collected in late July 2007. The number of fruit heads sampled was 17 for HER2, 9 for HOY and 15 for PIE1 (Table 4). The number of cypselas of these fruit heads was recorded in the laboratory. The number of cypselas per single fruit head (with and without paper bag) was compared with the number of flowers per fruit head. In total, the number of cypselas was recorded for 68 fruit heads with bag and 41 without bag.

\section{Cypsela collection and storage}

Ripe cypselas from mature fruit heads taken in July 2007 for evaluating the number of fruits per head were used for the germination experiments. Cypselas belonging to subpopulations HER2, NAV2 and SAN were cleaned manually (immature cypselas or cypselas attacked by parasites were eliminated), placed in paper bags and stored dry under laboratory conditions at about $23^{\circ} \mathrm{C}$ until the start of the 
Table 9. Final germination percentages and mean germination time (MGT) of Senecio coincyi cypselas belonging to a single fruit head. Fruit heads (from 3 to 5) were taken from three individual plants of the subpopulation PEV and four plants of HER2. The number of empty cypselas in each replicate was taken into account for calculating the final germination percentage. Results after 20 days of incubation under a $16-\mathrm{h}$ light photoperiod at $25 / 15^{\circ} \mathrm{C}$.

\begin{tabular}{|c|c|c|c|c|c|}
\hline $\begin{array}{l}\text { Subpop. } \\
\text { code }\end{array}$ & $\begin{array}{l}\text { Individual } \\
\text { plant }\end{array}$ & $\begin{array}{l}\text { Fruit } \\
\text { head }\end{array}$ & $\begin{array}{c}\text { Empty cypselas } \\
(\% \pm \text { SE })\end{array}$ & $\begin{array}{l}\text { Germination } \\
\quad(\% \pm \mathrm{SE})\end{array}$ & $\begin{array}{c}\text { MGT } \\
\text { (days } \pm \text { SE) }\end{array}$ \\
\hline \multirow[t]{18}{*}{ PEV } & \multirow[t]{6}{*}{1} & 1 & $8 \pm 2.83$ & $89 \pm 1.70$ & $9.68 \pm 0.18$ \\
\hline & & 2 & $2 \pm 1.41$ & 100 & $10.09 \pm 0.37$ \\
\hline & & 3 & $6 \pm 4.24$ & $96 \pm 0.27$ & $9.97 \pm 0.18$ \\
\hline & & 4 & 0 & 100 & $9.34 \pm 0.02$ \\
\hline & & 5 & $16 \pm 0.00$ & $83 \pm 2.38$ & $9.17 \pm 0.00$ \\
\hline & & $P$ & 0.1551 & 0.0001 & 0.0847 \\
\hline & \multirow[t]{6}{*}{2} & 1 & $4 \pm 0.00$ & $96 \pm 4.17$ & $7.98 \pm 0.44$ \\
\hline & & 2 & 0 & $92 \pm 4.00$ & $8.84 \pm 0.43$ \\
\hline & & 3 & 0 & 100 & $9.98 \pm 0.10$ \\
\hline & & 4 & $8 \pm 2.83$ & $98 \pm 2.08$ & $9.51 \pm 0.10$ \\
\hline & & 5 & $4 \pm 2.83$ & $92 \pm 0.35$ & $9.66 \pm 0.08$ \\
\hline & & $P$ & 0.1384 & 0.2332 & 0.0219 \\
\hline & \multirow[t]{6}{*}{3} & 1 & 0 & 100 & $9.14 \pm 0.90$ \\
\hline & & 2 & $2 \pm 1.41$ & $98 \pm 2.08$ & $9.88 \pm 0.08$ \\
\hline & & 3 & $10 \pm 4.24$ & $93 \pm 7.14$ & $9.30 \pm 0.09$ \\
\hline & & 4 & 0 & $98 \pm 2.00$ & $8.79 \pm 0.09$ \\
\hline & & 5 & 0 & $94 \pm 2.00$ & $9.30 \pm 0.12$ \\
\hline & & $P$ & 0.0742 & 0.6035 & 0.5244 \\
\hline \multirow[t]{18}{*}{ HER2 } & \multirow[t]{4}{*}{1} & $\begin{array}{l}1 \\
2\end{array}$ & $\begin{array}{r}2 \pm 1.41 \\
16 \pm 8.48\end{array}$ & $\begin{array}{c}98 \pm 2.00 \\
100\end{array}$ & $\begin{array}{l}7.71 \pm 0.50 \\
7.75 \pm 0.75\end{array}$ \\
\hline & & 3 & $18 \pm 4.24$ & $95 \pm 4.55$ & $8.03 \pm 0.33$ \\
\hline & & 4 & $6 \pm 1.41$ & 100 & $6.63 \pm 0.38$ \\
\hline & & $P$ & 0.2914 & 0.6021 & 0.3551 \\
\hline & \multirow[t]{4}{*}{2} & 1 & $20 \pm 2.83$ & $87 \pm 8.15$ & $10.08 \pm 0.28$ \\
\hline & & 2 & $46 \pm 9.90$ & $95 \pm 5.00$ & $10.97 \pm 0.14$ \\
\hline & & 3 & $4 \pm 0.00$ & $96 \pm 0.00$ & $10.57 \pm 0.04$ \\
\hline & & $P$ & 0.0492 & 0.5711 & 0.0877 \\
\hline & \multirow[t]{5}{*}{3} & 1 & $14 \pm 1.41$ & 100 & $11.81 \pm 0.33$ \\
\hline & & 2 & $62 \pm 1.41$ & $94 \pm 5.56$ & $12.38 \pm 0.13$ \\
\hline & & 3 & $16 \pm 5.66$ & 100 & $12.20 \pm 0.36$ \\
\hline & & 4 & $38 \pm 1.41$ & $70 \pm 23.54$ & $12.03 \pm 0.17$ \\
\hline & & $P$ & 0.0095 & 0.2145 & 0.5417 \\
\hline & \multirow[t]{5}{*}{4} & 1 & $34 \pm 10.00$ & $92 \pm 7.89$ & $10.67 \pm 0.11$ \\
\hline & & 2 & $32 \pm 2.83$ & $78 \pm 22.22$ & $11.60 \pm 1.60$ \\
\hline & & 3 & $24 \pm 15.56$ & $93 \pm 7.14$ & $11.96 \pm 0.29$ \\
\hline & & 4 & $6 \pm 1.41$ & 100 & $8.52 \pm 0.65$ \\
\hline & & $p$ & 0.3584 & 0.7491 & 0.1516 \\
\hline
\end{tabular}

$P$ significant values in bold

germination trials in December 2007 and January 2008. For each subpopulation, cypselas belonging to fruit heads from different individuals were bulked. Cypselas collected in July 2007 were used for studying the effect of different temperature regimes and light conditions on the germination behavior of $S$. coincyi.

Likewise, ripe fruit heads containing mature cypselas were taken from six subpopulations (HER2, 
NAV1, PIE1, PEV, SAN and TIE) in July 2008. The criterion followed for choosing these subpopulations was that they be representatives of the distribution of $S$. coincyi. Subpopulations were then chosen from the two sectors in the distribution of this species, the western and eastern sectors (Fig. 1, Table 1). In the eastern sector, only two known subpopulations (TIE and PEV), which were quite distant from one another, were selected. Within the western sector, better preserved subpopulations, such as HER2 and SAN, and those that are at the greatest risk of extinction, such as NAV1, were selected. The criterion followed to select the fruit heads was their complete ripeness. The cypselas from all selected fruit heads showed a similar degree of ripeness, as observed from their color and hardness. As above, all fruit samples were cleaned manually, placed in paper bags and stored dry under laboratory conditions (ca. $23^{\circ} \mathrm{C}$ ) until use in October 2008. Cypselas collected in July 2008 were used for studying the possible intraspecific germination variability of $S$. coincyi.

\section{Germination trials}

Four replicates of 25 cypselas each were tested for germination on top of two sheets of filter paper (previously moistened with $3.5 \mathrm{ml}$ distilled water) in 7 $\mathrm{cm}$ diameter glass Petri dishes. Filter papers were rewetted regularly with distilled water as required. Dishes were checked three times a week over a total 20-day test period and germinated cypselas were counted and removed. The criterion for germination was visible radicle protrusion. In all trials, at the end of the incubation period, ungerminated cypselas were checked by cutting open each cypsela to see if an embryo was present and looked healthy. The number of empty cypselas in each replicate was taken into account for calculating the final germination percentage.

\section{Effect of temperature and light regimes on cypsela germination}

The aim of this trial was to determine the optimal temperature and light requirements for radicle emergence. In December 2007 and January 2008, germi- nation of cypselas belonging to the subpopulations HER2 and NAV2 collected in July 2007 was tested at different constant temperatures $\left(10^{\circ} \mathrm{C}, 15^{\circ} \mathrm{C}, 20^{\circ} \mathrm{C}\right.$, $25^{\circ} \mathrm{C}$ and $30^{\circ} \mathrm{C}$ ) with a $16 \mathrm{~h}$ light photoperiod (provided by cool white fluorescent tubes with an irradiance of $\left.35 \mu \mathrm{mol} \cdot \mathrm{m}^{-2} \cdot \mathrm{s}^{-1}\right)$ and alternate temperatures of $25^{\circ} \mathrm{C} / 15^{\circ} \mathrm{C}$ (at $25^{\circ} \mathrm{C}$ for $16 \mathrm{~h}$ in the light, and at $15^{\circ} \mathrm{C}$ for $8 \mathrm{~h}$ in the dark). For the lowest incubation temperature assayed $\left(10^{\circ} \mathrm{C}\right)$, the germination period was extended to 40 days. In addition, cypselas belonging to the subpopulation SAN collected in July 2007 were tested for germination at alternate temperatures of $25 / 15^{\circ} \mathrm{C}$ under a $16 \mathrm{~h}$ light photoperiod, and additionally under constant darkness. Darkness treatment was obtained by wrapping the Petri dishes in a double layer of aluminum foil. For each one of the two subpopulations, the cypselas from all fruit heads collected from different individual plants were bulked.

\section{Intraspecific variation in cypsela germination}

Germination trials were carried out in order to detect germination differences among subpopulations. In October 2008, germination of cypselas belonging to six subpopulations (HER2, NAV1, PIE1, PEV, SAN, TIE) collected in July 2008 was tested at $25^{\circ} \mathrm{C} / 15^{\circ} \mathrm{C}$ under a $16 \mathrm{~h}$ light photoperiod. In every subpopulation, the cypselas from all fruit heads collected from different individuals were bulked.

Germination experiments were carried out for detecting germination differences among individuals belonging to the same subpopulation. Ripe fruit heads from several individuals chosen at random and belonging to the subpopulations HER2 (13 individuals) and SAN (12 individuals), were collected in July 2008 and kept separately prior to cypsela extraction. Then, for each individual plant, cypselas from all fruit heads harvested were bulked. In October and November 2008, the cypselas from individuals were set to germinate at $25^{\circ} \mathrm{C} / 15^{\circ} \mathrm{C}$ under a $16 \mathrm{~h}$ light photoperiod. In the same way, ripe fruit heads (from 3 to 5) belonging to several individuals randomly chosen from the subpopulations HER2 (4 individuals) and PEV ( 3 individuals), were harvested in July 2008 and kept separate prior to cypsela extraction. Then, 
the cypselas from each fruit head were collected and kept separately (without bulking). In November and December 2008, the cypselas from the different fruit heads were germinated at $25^{\circ} \mathrm{C} / 15^{\circ} \mathrm{C}$ under a $16 \mathrm{~h}$ light photoperiod.

\section{Data analysis}

At the end of the germination period, the final germination percentage (mean value \pm standard error) and the mean germination time (MGT, mean value in days \pm standard error) were calculated. The latter was determined according to the following formula (Ellis \& Roberts 1981): MGT $=\Sigma$ DN / $\Sigma \mathrm{N}$; where $\mathrm{D}$ is the number of days counted from the date of sowing and $\mathrm{N}$ is the number of seeds germinated on day D. In all germination trials, the number of empty cypselas in each replicate was taken into account for calculating the final germination percentage.

The values of final germination percentages were arcsine transformed and then subjected to analysis of variance (untransformed data appears in Tables). One-way factorial ANOVA was used to test the effects of the different temperature regimes and light conditions (light/dark and constant darkness) on seed germination capacity. Similarly, to determine differences among the germinations of cypselas belonging to different subpopulations, individuals and single fruit heads, data were analyzed by means of one-way ANOVA. Where ANOVA indicated a significant effect, a comparison of mean values was carried out through the least significant difference test (LSD). The statistical analysis of MGT was also carried out using one-way factorial ANOVA.

\section{RESULTS}

\section{Habitat types where S. coincyi grows}

Approximately half of the area of occupancy of $S$. coincyi is composed of the edges of streams (Table 2). These habitats range from streams $1-2 \mathrm{~m}$ in width at the bottom of more or less open valleys, to small creeks descending from the upper parts of watersheds with steep slopes. The type of habitat that is best represented are hay meadows, representing $30 \%$ of the total area occupied by S. coincyi (Table 2). Many of these meadows are now abandoned, but herbaceous communities of high demand of water are still present because they maintain constant soil moisture during the summer period. About $20 \%$ of the total area of occupation (Table 2) consists of naturally flooded meadows that were never used as hay meadows. This is a highly fragmented habitat type, consisting of very small strips of land, most of them barely reaching half a hectare. The water pipes that were built for agricultural and livestock purposes represent a very small percentage of $S$. coincyi habitats, only 3\% (Table 2). Around these channels, the soil maintains high moisture and allows the growth of small groups of individuals of this species (usually not more than 4 or 5 individuals were found together). Peat bogs represent only $1 \%$ of habitats occupied by this species (Table 2), but are part of a unique ecosystem that is worth preserving.

\section{Number of mature individuals}

The total number of mature individuals was approximately 26000 , distributed in 13 subpopulations over almost 30 ha (Table 1). The number of individuals ranged widely from cca. 10000 for the biggest subpopulation (11.2 ha) to less than 50 for the smallest subpopulation (0.1 ha) (Table 1). Subpopulations were located in two different sectors (Table 1), clearly differentiated by the distance between them: the western sector was mainly located in the Sierra of Villafranca, and the eastern sector on the southern slope of the Sierra of Gredos, with one of their only two subpopulations near the border with the province of Madrid. Three of the localized subpopulations of $S$. coincyi are included in protected natural areas: NAV1 and HOY in the Parque Regional of Sierra of Gredos, and TIE in the Reserva Natural of Valle of Iruelas.

\section{Natural pollination in the field and number of flowers per fruit head}

The reproduction of $S$. coincyi is sexual and characterized by a high plasticity regarding insect 
pollinators. The most important groups of insect visitors to its flowers were Hymenoptera, Lepidoptera, Diptera and Coleoptera. Therefore, S. coincyi is a generalist entomophilous species. Sexually mature individuals issued a floriferous stem that usually carried between 10 and 20 fruit heads. The proportion of adult flowering individuals observed in June 2007 was very high, ranging from 80 to $90 \%$ for most subpopulations. However, a lower percentage of flowering individuals was recorded in some subpopulations; for example, the HOY and TIE subpopulations had a $70 \%$ and $15 \%$, respectively, of adult flowering individuals. Flowering occurs throughout June and it starts at the apical tip of the stem.

Each fruit head is composed by two types of flowers: hermaphrodite flowers (tubular flowers) occupying the central part of fruit heads, and female unisexual flowers (ligulate flowers), which are arranged in a circle. The mean number of flowers (both ligulate and tubular) per single fruit head is shown in Table 3. The mean number of ligulate and tubular flowers per fruit head is also shown. No significant differences in the number of tubular flowers $(P=0.1268)$ and total number of flowers $(P=0.1135)$ per fruit head were found among the subpopulations. However, significant differences $(P=0.0012)$ in the number of ligulate flowers per fruit head were found among the subpopulations. In addition, no significant differences $(P>0.05)$ in the number of ligulate, tubular or total flowers per fruit head were found among individuals belonging to the same subpopulation. The mean value of flowers per fruit head was $163 \pm 3.34$ (246 maximum-78 minimum) for 114 collected fruit heads belonging to seven subpopulations.

\section{Number of cypselas per fruit head}

The fruiting period occurs between late June and July. The first fruit head that mature is the central, and fruits some days before the others. The mean value of cypselas per fruit head for all subpopulations sampled was $146 \pm 4.13$ (237 maximum-71 minimum) for 68 heads collected without a paper bag, and $165 \pm 6.20$ (290 maximum-102 minimum) for 41 heads collected with a paper bag (Table 4 ). The mean number of cypselas and flowers per fruit heads was very similar (see Tables 3 and 4). Therefore, the proportion of flowers setting fruits was very high, indicating that most of flowers were fertilized. The sterile flower percentages and/or aborted cypselas observed were very low, indicating that $S$. coincyi produces a large amount of ripe cypselas per year. In addition, this species is characterized by a remarkable facility to spread its cypselas, because they have a pappus facilitating its dispersion by wind. For all subpopulations sampled, no significant differences $(P>0.05)$ in the number of cypselas per fruit head were found among individuals from the same subpopulation. Similarly, no significant differences $(P>0.05)$ in the number of cypselas per fruit head were found among subpopulations.

\section{Number of fruit heads per individual plant}

The mean number of fruit heads per individual plant is shown in Table 5. The mean value of fruit heads per individual was $13 \pm 0.56$ (44 maximum-3 minimum) for 127 sampled individuals belonging to five subpopulations. Significant differences $(P=0.0008)$ in the number of fruit heads per individual plant were found among the subpopulations. However, no significant differences $(P>0.05)$ were found among individuals belonging to the same subpopulation.

\section{Effect of incubation temperatures}

The effect of incubation temperature on the germination of cypselas from subpopulations HER2 and NAV2 is shown in Table 6. Significant differences $(P<0.05)$ were found among the temperature regimes assayed for the final germination percentages reached by cypselas belonging to HER2. The highest germination $(100 \%)$ was reached at $25^{\circ} \mathrm{C}$ and the lowest $(19 \%)$ at $10^{\circ} \mathrm{C}$. However, when the lowest temperature was not considered, no significant differences $(P>0.05)$ were found among the other three temperatures. Similarly, no significant differences $(P>0.05)$ were found among the three temperatures assayed for NAV2. MGT values showed significant differences $(P<0.05)$ for HER2 and no significant differences were found for NAV2. The cypselas of 
HER2 germinated faster at $25^{\circ} \mathrm{C}, 20^{\circ} \mathrm{C}$ and at $25^{\circ} \mathrm{C}$ $/ 15^{\circ} \mathrm{C}$ than at $15^{\circ} \mathrm{C}$ and $30^{\circ} \mathrm{C}$. Germination was significantly delayed at the lowest temperature assayed $\left(10^{\circ} \mathrm{C}\right)$. Both subpopulations exhibited very high germination percentages $(90-100 \%)$ and high rates of germination (5.87-7.96 days) in all incubation temperatures tested (except at $\left.10^{\circ} \mathrm{C}\right)$. Cypselas from HER2 reached lower MGT values at $20^{\circ} \mathrm{C}, 25^{\circ} \mathrm{C}$ and $25^{\circ} \mathrm{C} / 15^{\circ} \mathrm{C}$ than those from NAV2.

\section{Effect of light conditions}

The effect of light conditions on germination was studied for cypselas belonging to the SAN subpopulation. Cypselas were set to germinate at $25^{\circ} \mathrm{C} / 15^{\circ} \mathrm{C}$ under a $16 \mathrm{~h}$ light photoperiod or constant darkness. Final germination percentages reached under the photoperiod and complete darkness were very simi$\operatorname{lar}(94 \% \pm 2.24 \%$ and $91 \% \pm 5.93 \%$, respectively). Germination percentage was not significantly affected by light conditions $(P=0.8448)$. However, significant differences $(P=0.0108)$ were found between the photoperiod and darkness for the MGT values. Cypselas reached lower MGT values under a $16 \mathrm{~h}$ light photoperiod ( $8.82 \pm 0.28$ days) than under constant darkness ( $9.99 \pm 0.15$ days).

\section{Intraspecific variation in cypsela germination}

The germination of cypselas belonging to six subpopulations is shown in Table 7. Significant differences $(P<0.05)$ were found among subpopulations for the final germination percentages (from $88 \%$ to $99 \%$ ) and MGT values (from 6.93 to 8.91 days). Similarly, the number of empty cypselas varied significantly among the subpopulations (from $0 \%$ to $42 \%$ ).

Germination of cypselas belonging to different individuals of the subpopulations HER2 and SAN are shown in Table 8. In both subpopulations, the number of empty cypselas varied significantly ( $P=0.0004$ and $P=0.0094$, respectively) among individual plants (from $0 \%$ to $46 \%$ for HER2 and $0 \%$ to $44 \%$ for SAN). Similarly, MGT values showed significant differences ( $P=0.0001$ for both subpopulations). However, in every population no significant differ- ences ( $P=0.0747$ and $P=0.2821$, respectively) were found among individuals for the final germination percentages (from $84 \%$ to $100 \%$ for HER 2 and $90 \%$ to $100 \%$ for SAN).

Table 9 shows the germination characteristics of cypselas belonging to different fruit heads of several individuals from the subpopulations PEV and HER2. No significant differences were found in most of the cases studied. Only for one individual plant of PEV did the final germination percentage vary significantly ( $P=0.0001)$ among the fruit heads. Similarly, significant differences $(P=0.0219)$ were found among the MGT values reached by cypselas of a single head from just one individual plant of this same population. The number of empty cypselas did not vary significantly $(P>0.05)$ among the fruit heads from individuals of $\mathrm{PEV}$, but significant differences were found for two individuals from HER2 $(P=0.0492$ and $P=0.0095$ ).

\section{DISCUSSION}

S. coincyi grows in a very small area within the supra- and oromediterraneous bioclimatic stages of the Sierras of Villafranca and Gredos. All subpopulations known are located in Âvila province (central western Spain). The water requirements of this species removed from the list of possible locations those whose soils did not maintain a high level of humidity throughout the year. These strict water requirements only can be satisfied at certain sites that can be grouped into five different habitat types: edges of streams, hay meadows, peaty meadows, peat bogs and water pipes.

The flowers of $S$. coincyi are pollinated by several insect species. Arrabal et al. (2011) found that the main compound of the essential oil of $S$. coincyi leaves is 1-tridecene. This compound is known to be secreted by several insect groups (Coleoptera, Hymenoptera) and has pheromone properties. The presence of a high concentration of 1-tridecene in this species could indicate an important ecological function: it acts as a potent sexual attractant to different insects species that transport the pollen. 
Results from this study highlight the high reproductive capacity of $S$. coincyi based on a high production of fruit heads, flowers and cypselas. Their cypselas have a pappus that facilitates its dispersion by wind and most ripe cypselas produced are viable and germinate readily in a wide temperature range, both under light and darkness. Multiplying the total number of individuals recorded in 2007 (25613) by the approximate ratio of flowering individuals of this year $(0.8)$ by the mean number of fruit heads per individual plant (13) by the mean number of cypselas per fruit head (165), we get an output of more than 40 million cypselas at the fruiting time.

Very high germination percentages were reached under laboratory conditions, even higher than those reached by others species of the genus Senecio that also grow in mountain habitats, such as $S$. integrifolius (Widén, 1987), S. boissieri and S. pyrenaicus (Giménez-Benavides et al., 2005). Moreover, the ability to germinate over a wide range of temperatures frequently occurs in many Asteraceae species (Baskin and Baskin, 1998; Schütz et al., 2002). Cypselas reached germination percentages equal to or higher than $90 \%$ at temperatures between $15^{\circ} \mathrm{C}$ and $30^{\circ} \mathrm{C}$. However, the final germination percentage was lower than $20 \%$ at $10^{\circ} \mathrm{C}$. In addition, cypselas germinated both under a 16-h light photoperiod and under complete darkness. Therefore, light was not a crucial factor for the germination of this species. In conclusion, S. coincyi cypselas showed opportunistic germination behavior and they were able to germinate in wide range of temperature and light conditions.

Soil type and edaphic humidity are parameters that remain constant throughout the year in the habitats where the species grows. Therefore, the main environmental factor limiting cypsela germination and subsequent seedling survival under natural conditions would be the low temperatures. In the sites that S. coincyi inhabits, from June to September frost does not occur and the mean temperature of each month exceeds or is near to $15^{\circ} \mathrm{C}$. The results obtained in the germination trials were consistent with these data, because in these experiments it was shown that for temperatures higher than $10^{\circ} \mathrm{C}$ the final germination percentages were very high for cypselas from all the populations studied. In addition, cypselas readily germinated in all the temperatures tested (except $10^{\circ} \mathrm{C}$ ), as similarly reported for many temperate climate species around the world (Baskin and Baskin, 1998; Vandelook and Van Assche, 2008). Since mountain ecosystems are typically subjected to a short growing season, this strategy could be claimed to ensure enough time for seedling establishment (Chambers et al., 1987; Körner, 1999; Grime, 2001).

In general, we did not find intraspecific variability in relation to the germination pattern of $S$. coincyi cypselas. The variation in germination characteristics could be interpreted as one of the most important survival strategies for species growing under unpredictable environmental conditions (Kigel, 1995). However, all habitats where $S$. coincyi grows have very similar environmental characteristics and they are very stable. For example, all these habitats maintain high soil moisture content throughout the year. Therefore, it seems logical that there were not significant differences with regard to cypselas germination behavior among different subpopulations, individuals and fruit heads.

Assuming 20\% empty cypselas and a mean germination of $85 \%$ for viable cypselas (at temperatures higher than $10^{\circ} \mathrm{C}$ ) from the 40 million cypselas produced in a year, nearly 30 million will germinate and develop seedlings. These figures, although approximate and subject to a possible wide margin of error, would indicate that if only the reproductive characteristics of this species were taken into account, the total number of individuals could be much closer to the 30 million estimated than less than the 30000 individuals recorded in 2007.

The results of population demography are not very encouraging, in contrast to the very positive results concerning reproductive biology. The altitude, precipitation and temperature conditions, and, above all, high soil moisture needed for the germination and normal development of $S$. coincyi occur in a large number of potential sites that, taken together, 
could add a much larger area to that actually occupied by this species. We have personally witnessed the disappearance of two populations of this species located in Ávila and Zamora provinces (central western Spain). These two populations were cited more than two decades ago (García López and Roa Medina, 1988; Luceño and Vargas, 1991). In addition, its extent of occurrence presents a moderate fragmentation and some populations have a very small number of individuals, which could make them demographically unviable in a short time.

How can we explain that a species with a high reproductive potential does not grow in those sites that a priori have optimal conditions for its establishment? The explanation is in the fact that there are different factors that could damp the very high reproductive potential of this taxon, and they could greatly reduce the size and surface occupied by their different subpopulations.

Specific studies to verify the percentage of seedlings attacked by fungi, eaten by different animals, damaged by early or late frost, or victims of strong competition for resources with other plant species or their own members, were not carried out. Laboratory and field studies should be undertaken to evaluate the percentage of seedlings that fail to develop and die.

In our field observations, we have identified several factors that could be of serious threat to $S$. coincyi survival. Among them, the most important is undoubtedly livestock. In those sites frequented by livestock this species fails to form dense masses and their plants are broken and crushed. However, we have not seen great damages through their plants being eaten by livestock. Pyrrolizidine alkaloids are the most characteristic secondary metabolites present in the genus Senecio, and several of these compounds are hepatotoxic to mammals (Hartmann and Witte, 1995; Mattocks, 1989). Suau et al. (2002) found a high alkaloid content in three Spanish Senecio species ( $S$. elodes, S. granatensis and S. malacitanus). These toxic compounds could also be present in the aerial parts of $S$. coincyi so that livestock avoid eating it. There- fore, the danger of livestock for this species does not seem to result from direct consumption of plants or parts of them, but rather from the ecological disturbance caused by livestock in habitats where $S$. coincyi grows. Livestock cattle trampling, the major factor in these mountains, would favor the development of caespitose species with vegetative reproduction, such as grasses of genus Festuca or Nardus stricta, and not of sexually reproducing species such as $S$. coincyi.

This replacement of species typical of peat meadows by caespitose species is happening in many parts where $S$. coincyi occurs, and could explain, at least in part, the absence of this species in sites that would satisfy their ecological requirements (humidity, altitude, temperature). Because of this, the species grows mainly in sites with difficult or impossible access for cattle, such as hay meadows with the constant presence of water in the soil, and stone fences that prevent the entry of livestock. However, in recent decades, rural exodus has been the cause of these meadows being abandoned and, with them, the maintenance of fences being abandoned as well so that livestock enter and graze freely in them.

The primary natural habitat (preanthropogenic) of $S$. coincyi includes edges of streams, peaty meadows and peat bogs, comprising almost $70 \%$ of the total of area of occupancy, while the secondary habitat (anthropogenic) includes hay meadows and water pipes (i.e. the remaining $30 \%$ ). S. coincyi is a species linked to permanently wet soils, so a small change in the hydrological regime of the streams where it grows could be lethal for their survival. More than half the area of occupancy of this species is represented by the edges of streams, and this fact implies that any change involving a reduction or elimination of the flow of these waterways is a serious threat to the conservation of $S$. coincyi.

S. coincyi was catalogued as Vulnerable (VU) in the 2008 Red List (Martínez García, 2008). Although $S$. coincyi is not in danger of imminent extinction, we consider necessary to implement, as soon as possible, several management measures for the conservation of this species. For example, one of the most fragile 
ecosystems in which it grows is peat bogs. These ecosystems represent only $1 \%$ of the area of occupancy of this species and they are only present in 4 of the 13 known subpopulations. In 3 of these subpopulations (HER2, NAV, PIE1) cattle have free access, so these peat bogs should be fenced to prevent their degradation. Similarly, reconstruction and periodic maintenance of the stone fences in hay meadows in all known subpopulations is essential.

In June 2007, the Official Gazette of the Autonomous Community of Castile and León published Decree 63/2007 that established the List of Protected Flora of Castile and Leon and the legal form of protection called 'Flora Micro-Reserves'. The micro-reserve concept is fully concurrent with the protection measures for $S$. coincyi, because its aim is protected sites that are small in area (less than $200 \mathrm{ha}$ ) for hosting the outstanding populations of threatened species included in this List. The species has the highest degree of protection that this List provides, being included in the 'In danger of extinction' category. We propose the inclusion of a part of the subpopulation HER2 area in the legal figure of "Flora Micro-Reserves'. This subpopulation spreads over a northwestoriented slope between the Sierras of Villafranca and Gredos; it is located between altitudes of $1470 \mathrm{~m}$ and $1689 \mathrm{~m}$ and occupies a central position within extent of occurrence of $S$. coincyi. Besides, it is the largest known subpopulation of this species with more than 10000 individuals, representing about $34 \%$ of all individuals of this taxon. Therefore, if this site were to be included as a micro-reserve it would be preserving a high percentage of the total individuals of $S$. coincyi. In addition, to protect the proposed area (ca. $6 \mathrm{ha}$ ) would at the same time imply the protection of mountain habitats of high ecological value. These habitats are rare in the Mediterranean mountains and they host a very specific flora and fauna, in many cases of relict character.

In conclusion, $S$. coincyi is a narrow and threatened endemic species for which conservation has become a necessary strategy. The results obtained in the present study highlight the sexual reproduction ability of this species, and therefore indicate that its conservation problems are not due to factors related to its reproductive biology, but mostly to others, such as the alteration of their habitats caused by the continuous and intense presence of livestock. This is the first report on the reproductive biology of $S$. coincyi.

Acknowledgments - This work was supported by the projects Inventario Nacional de Biodiversidad. Atlas de Flora Vascular Amenazada de España 3 (2007-2008). Estudio y evaluación de Senecio coincyi Rouy (Ministerio de Educación y Ciencia, Spain)' and 'Convenio específico de colaboración entre la Universidad de León y la Consejería de Medio Ambiente de la Junta de Castilla y León para la realización de trabajos cientificos vinculados al desarrollo del Decreto 63/2007 (Comunidad Autónoma de Castilla y León)'. We also want to thank Elena Bermejo, Carlos Morla, Enrique Rico, Alberto Talaván, Fernando Moreno, Juan López and Bernardo García for their help in this work.

\section{REFERENCES}

Albert, M.J., Iriondo, J.M., and F. Pérez-García (2002). Effects of temperature and pretreatments on seed germination of nine semiarid species from NE Spain. Israel J. Plant Sci. 50, 103-112.

Anonymous (2007). DECRETO 63/2007, de 14 de junio, por el que se crean el Catálogo de Flora Protegida de Castilla y León y la figura de protección denominada Microrreserva de Flora. B.O.C. y L., 119, de 20 de junio 2007. Available via http://noticias.juridicas.com/base_datos/CCAA/cld63-2007.html.

Arrabal, C., Martínez García, F., Arraiza, M.P., and S. Guerrero (2011). Chemical composition of essential oil of Senecio coincyi, an endemic species of the Central Iberian Peninsula. Natural Product Communications 6, 123-126.

Barreno, E. (1985). Listado de plantas endémicas, raras o amenazadas de España. Información Ambiental MOPU 3, 4871 .

Baskin, C.C., and J.M. Baskin (1998). Seed ecology, biogeography, and evolution of dormancy and germination. Academic Press, San Diego.

Chambers, J.C., McMahon, J.A., and R.W. Brown (1987). Germination characteristics of alpine grasses and forbs, a comparison of early and late serial dominants with reclamation potential. Reclam. Reveg. Res. 6, 235-249.

Cowling, R.M., Rundel, P.W., Lamont, B.B., Arroyo, M.K., and M. Arianoutsou (1996). Plant diversity in Mediterraneanclimate regions. Trends Ecol. Evol. 11, 352-360. 
Domínguez, F. (2000). Lista Roja de la flora vascular española. Conservación Vegetal, 6, 11-38.

Ellis, R.H., and E.H. Roberts (1981). The quantification of ageing and survival in orthodox seeds. Seed Sci. Technol. 9, 373-409.

Fernández, M., Ezcurra, C., Quiroga, M.P., and A.C. Premoli (2011). Genetic variation relevant for the conservation of the narrow endemic Senecio carbonensis (Asteraceae) from the Southern Andes. Plant Spec. Biol. 26, 145-157.

García López, P., and A. Roa Medina (1988). Dos nuevos táxones para el valle de Sanabria (Zamora). Anales del Jardín Botánico de Madrid 45, 353-354.

Gavilán, R.G., Fernández-González, F., and S. Rivas-Martínez (2001). Variaciones bioclimáticas en Madrid: un estudio sobre cambio climático local, In: Vegetación y cambios climáticos (Eds. F. Gómez, and J. F. Mota), 243-256. Servicio de Publicaciones de la Universidad de Almería, Almería.

Gavilán, R.G., Sánchez-Mata, D., Escudero, A., and A. Rubio (2002). Spatial structure and interactions in Mediterranean high mountain vegetation (Sistema Central, Spain). Israel J. Plant Sci. 50, 217-228.

Giménez-Benavides, L., Escudero, A., and F. Pérez-García (2005). Seed germination of high mountain Mediterranean species: altitudinal, interpopulation and interannual variability. Ecol. Res. 20, 433-444.

Gómez-Campo, C. (1987) Libro Rojo de las especies vegetales amenazadas de España peninsular e islas Baleares. Madrid: ICONA.

Grabherr, G., Gottfried, M., and H. Pauli (1994). Climate effects on mountain plants. Nature 369, 448.

Grime, J.P. (2001). Plant strategies, vegetation processes, and ecosystems properties. John Wiley \& Sons, Chichester.

Hartmann, T., and L. Witte (1995). Chemistry, biology and chemoecology of the pyrrolizidine alkaloids, In: Alkaloids: chemical and biological perspectives, vol 9 (Ed. S. W. Pelletier), 152-233). Pergamon, Oxford.

Iriondo, J.M. (2003). Atlas de flora amenazada. Manual de metodología del trabajo corológico y dernográfico. Ministerio de Medio Ambiente, Madrid.

Iriondo, J.M., Albert, M.J., Giménez-Benavides, L., Domínguez Lozano, F., and A. Escudero (2009). Poblaciones en peligro: viabilidad demográfica de la flora vascular amenazada de España. Dirección General de Medio Ambiente y Política Forestal (Ministerio de Medio Ambiente, y Medio Rural y Marino), Madrid.

IUCN Standards and Petitions Subcommittee (2010). Guidelines for the IUCN Red List Categories and Criteria. Version 8.1.
Prepared by the standards and Petitions Subcommittee in March 2010. Downloadable from http.//intranet.iucn.org/ webfiles/dos/SSC/redList/RedListGuidelines.pdf.

Kigel, J. (1995). Seed germination in arid and semiarid regions, In: Seed development and germination (Eds. J. Kigel, and G. Galili), 645-699. Marcel Dekker, New York.

Kirmizi, S., Güleryüz, G., and H. Arslan (2011). Germination responses to $\mathrm{GA}_{3}$ and short-time chilling of three endemic species: Tripleurospermum pichleri, Cirsium leucopsis and Senecio olympicus (Asteraceae). Plant Spec. Biol. 26, 5157.

Körner, C. (1999). Alpine plant life. Springer, Berlin.

Lorite, J., Ruiz-Girela, M., and J. Castro (2007). Patterns of seed germination in Mediterranean mountains: study on 37 endemic or rare species from Sierra Nevada, SE Spain. Candollea 62, 5-16.

Luceño, M. and P. Vargas (1991). Guía botánica del Sistema Central español. Ediciones Pirámide, Madrid.

Martínez Garcia, F. (2008). Senecio coincyi, In: Lista Roja 2008 de la flora vascular española amenazada (Ed. J.C. Moreno), Ministerio de Medio Ambiente, y Medio Rural y Marino, Madrid.

Martínez García, F., Garcia-Amorena, I., Rubiales, J.M., Guerrero-García, S., and S. García Álvarez (2008). Senecio coincyi, In: Atlas y Libro Rojo de la flora vascular amenazada de España. Adenda 2008 (Ed. A. Bañares, G. Blanca, J. Güemes, J.C. Moreno, and S. Ortiz). Ministerio de Medio Ambiente, y Medio Rural y Marino y Sociedad Española de Biología de la Conservación de Plantas, Madrid.

Mattocks, A.R. (1989). Chemistry and toxicology of pyrrolizidine alkaloids. Academic Press, New York.

Moreno, J.C. (2008). Lista Roja de la flora vascular española amenazada. Ministerio de Medio Ambiente, y Medio Rural y Marino, Madrid.

Ninyerola, M., Pons, X., and J.M. Roure (2005). Atlas climático digital de la Península Ibérica. metodología y aplicaciones en bioclimatología y geobotánica. Universidad Autónoma de Barcelona, Bellaterra, Barcelona.

Pérez-García, F., Iriondo, J. M., González-Benito, M.E., Carnes, L.F., Tapia, J., Prieto, C., Plaza, R., and C. Pérez (1995). Germination studies in endemic plant species of the Iberian Peninsula. Israel J. Plant Sci. 43, 239-247.

Peñuelas, J., Filella, I., and P. Comas (2002). Changed plant and animal life cycles from 1952 to 2000 in the Mediterranean region. Global Change Biol. 8, 531-544.

Rouy, M.G. (1890). Diagnoses de plantes nouvelles pour la flore européenne. Bulletin de la Société Botanique de France 3, 162-164. 
Sanz-Elorza, M., Dana, E.D., González, A., and E. Sobrino (2003). Changes in the high-mountain vegetation of the Central Iberian Peninsula as probable sign of global warming. Ann. Bot. 92, 273-280.

Schütz, W., Milberg, P., and B.B. Lamont (2002). Seed dormancy, after-ripening and light requirements of four annual Asteraceae in south-western Australia. Ann. Bot. 90, 707-714.

Suau, R., Cabezudo, B., Rico, R., Nájera, F, López-Romero, J.M., and A.I. García (2002). Pyrrolizidine alkaloids from three Spanish Senecio species. Biochem. System. Ecol. 30, 981-984.

Tutin, T.G., Heywood, V.H., Burges, N.A., Valentine, D.H., Walters, S.M., and D.A. Webb (1964-1980). Flora Europaea $I-V$. Cambridge University Press, Cambridge.
Vandelook, F, and J.A. Van Assche (2008). Temperature requirements for seed germination and seedling development determine timing of seedling emergence of three monocotyledonous temperate forest spring geophytes. Ann. Bot. 102, 865-875.

Väre, H., Lampinen, C., Humphries, C., and P. Williams (2003). Taxonomic diversity of vascular plants in the European alpine areas, In: Alpine biodiversity in Europe. Ecological Studies Vol 167 (Ed. L. Nagy), 133-1489. Springer, Berlin.

Widén, B. (1987). Population biology of Senecio integrifolius (Compositae), a rare plant in Sweden. Nordic J. Bot. 7, 687-704. 